Stellenbosch Theological Journal 2020, Vol 6, No 3, 277-300

DOI: http://dx.doi.org/10.17570/stj.2020.v6n3.a9

Online ISSN 2226-2385 | Print ISSN 0028-2006

2020 ๑ Pieter de Waal Neethling Trust

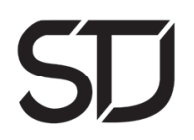

\title{
Die Afrikaanse gereformeerde kerke in Suid-Afrika en ekologie
}

\author{
Rikus (PH) Fick \\ Akademie Reformatoriese Opleiding en Studies (AROS) \\ Pretoria, Suid-Afrika \\ rikus.fick@aros.ac.za
}

Abstract

\section{The Afrikaans reformed churches in South Africa and ecology}

A plethora of studies describing the scope of destruction of the ecology has been published since the 1970s. Lately, Christianity has been accused of being partly responsible for this. Despite the fact that South Africa is one of the ten largest polluters in the world, local religious communities only started voicing an opinion on this matter during the late 1980s. Only in the early 1990s did the reformed churches in South Africa begin some soul searching and the matter was placed on the agenda. The question raised in this article is: What contribution have the reformed churches in South Africa made towards averting this crisis? The author considers criticism levelled at Christianity in general and at the reformed churches in particular; the status of ecology in the dogma of these churches; the contributions made by theologians, and important decisions taken by synods. Three phases were noted in the way the synods dealt with the issue: Firstly, it was acknowledged that a crisis exists and that the church is neither innocent nor can she remain indifferent; secondly, theologians reflected deeply on this matter and offered a refined formulation of a creed to articulate the relationship between God, creation and man. Lastly, practical guidelines were proposed. It was found that the reformed churches have contributed significantly towards alerting people to the fact that the crisis also has religious implications; that the faithful should obey Biblical guidelines; and that there are implications for life, liturgy, education, and theological training.

\section{Trefwoorde}

Ekologie; omgewing; gereformeerde kerke; eko-teologie; eko-geregtigheid

\section{Inleiding - die ekologiese krisis}

Sedert die jare sewentig van die vorige eeu het 'n stortvloed wetenskaplike studies die lig gesien wat die omvang van die vernietiging van die aarde 
se ekologie beskryf. Dit behels die prosesse wat die aarde se ekosisteme en ekologiese siklusse beïnvloed en ook die bedreiging van die boustene van lewe (Conradie 2003:126). Dit word dikwels as 'n "krisis" beskryf en die term "ekologiese wanhoop" word ook gebruik om die omvang daarvan te beskryf. Wat die probleem vererger, is dat van die supermoondhede van die wêreld nie altyd hulle samewerking wil gee om besoedeling te bestry nie en boonop word Suid-Afrika beskou as een van die wêreld se tien grootste besoedelaars (Van Wyk 2015:12).

Verskeie navorsers het dit duidelik gemaak dat hierdie krisis nie net te doen het met die natuur op sigself nie, maar veral met die ingesteldheid van die mens. Dit is 'n kulturele probleem: die dominante, wêreldwye kultuur van ons tyd word gekenmerk deur verbruikersmanie ("consumerism") en dit word selfs as die ideologie van ons tyd beskou (Conradie \& Pauw 2002:407408; De Wet 2014:3). Gierigheid en winsbejag as aansporingsmaatreël in die besigheidswêreld wat die grense vir gesonde interaksie met die gemeenskap oorskry, word ook dikwels as 'n ingesteldheidsprobleem uitgewys (BedfordStrohm 2013:32).

In Suid-Afrika het daar eers in die laat 1980's stemme uit die geloofsgemeenskappe oor hierdie kwessie begin kom en teen die draai van die eeu het 'n aantal organisasies waarby geloofsgemeenskappe betrokke was, tot stand gekom. Die volgende is die belangrikste en word hieronder bespreek.

Van 26 Augustus tot 4 September 2002 het Suid-Afrika die World Summit on Sustainable Development aangebied. Tot die aanloop van die byeenkoms het 'n aantal teoloë en leiers uit die Christelike kerke in Suid-Afrika 'n gespreksdokument met die titel, The land is crying for justice: A discussion document on Christianity and environmental justice in South Africa saamgestel onder redakteurskap van dr Renier Koegelenberg. Hulle wou die dokument in dieselfde profetiese en ekumeniese gees as die Kairosdokument van 1985 en die Rustenburg-verklaring van 1990 die lig laat sien. The Network of Earthkeeping Christian Communities in South Africa (NECCSA) is terselfdertyd gestig met die doel om 'n netwerk vir plaaslike kerke, gemeenskappe, groepe, organisasies en individue te skep om met mekaar in gesprek te tree oor kwessies wat met omgewingsgeregtigheid te doen het. Dit het intussen ontbind. 
In 2005 is die Southern African Faith Communities' Environment Institute (SAFCEI) gestig. Dit is 'n multi-geloof organisasie wat daartoe verbind is om geloofsleiers en die gemeenskappe in Suider-Afrika waaraan hulle verbonde is, te ondersteun om bewustheid, begrip en optrede te bevorder wat eko-geregtigheid, volhoubare lewe en klimaatsverandering betref. Onder die lede van hierdie organisasie tel Afrika tradisionele genesers, Boeddhiste, Hindoes, Moslems, Jode, Kwakers en verskeie Christendenominasies (SAFCEI n.d., geraadpleeg op 7 Maart 2019).

Die vraag waaraan hierdie artikel egter aandag wil gee, is: Watter bydrae het die gereformeerde kerke in Suid-Afrika gelewer om hierdie krisis die hoof te bied? Om hierdie vraag te beantwoord word gekyk na kritiek op die Christendom in die algemeen en op die kerke in besonder, die plek wat ekologie in die dogma van die kerke inneem, die bydraes wat teoloë van die kerke in hierdie verband gelewer het, en belangrike besluite wat sinodes hieroor geneem het. 'n Kritiese, kerkhistoriese wyse van ondersoek is gevolg om hierdie vraag te beantwoord. Primêre en sekondêre bronne is geraadpleeg.

\section{Klag teen die Christendom}

Aanklagte teen die Christendom oor die hantering van die ekologiese krisis kom uit die geledere van ander gelowe, maar die hand is ook in eie boesem gesteek. Wat eersgenoemde betref, is daar veral drie aanklagte. Die eerste is teen Christelike werksetiek met die strewe om altyd jou beste te lewer, al is dit ten koste van die omgewing. Die tweede is veral teen die Katolieke Kerk se verbod op geboortebeperking te midde van die krisis van oorbevolking. Die derde is teen die roekeloosheid waarmee sakemanne van die Eerste Wêreld wat hulleself Christene noem, hulle projekte in arm lande uitvoer en grootskaalse armoede en omgewingsverwoesting agterlaat (Van der Walt 2005:20).

Uit feministiese geledere het daar verwyte gekom teen die manlike leierskap in Christelike instellings in Suid-Afrika en die invloed daarvan op ekologiese kwessies. Dit word toegeskryf aan 'n hiërargiese en dualistiese siening van die skepping waarin die man God se agent is wat na die aarde moet omsien wat geskep is vir sy eie welsyn en vir sy afhanklikes. Volgens Ackerman (1997:53-54) het dit die mans as heersersklas 'n ongebreidelde 
lisensie gegee om hulle heerskappy oor menslike en nie-menslike vorms van lewe uit te oefen.

Teen 1990 het daar ook verskeie stemme uit die gereformeerde kerke in Suid-Afrika self begin kom wat daarop gewys het dat die kerk nie koud kan staan teenoor die ekologiese krisis nie. Dit is immers ook 'n religieuse probleem. Oproepe dat die kerk moet reageer op hierdie krisis het al hoe duideliker begin klink. Buitendag (1988:297-298,302) was een van die eerste stemme uit hierdie geledere wat verskeie probleme uitgewys het: Ongehoorsaamheid, onbegrip, sekularisasie, die verkeerde verstaan van die mens se kultuuropdrag en 'n verkeerde siening van die mens, naamlik sy begrip van die imago Dei. Hy sê ook elders (soos aangehaal in Van Aarde \& Van Wyk, 2014:12): "Ek meen dat die kerk vir baie lank die mens se 'andersheid' met die natuur ten koste van die mens se 'eendersheid' met die natuur beklemtoon het."

Van der Walt (2014b:49-53) wys ook op die "ramp" van 'n onbybelse werklikheidsbeskouing en mensvisie wat die gevolg het dat die mens se verhouding tot God bloot vergeestelik word. Hiervolgens versmal dit tot iets vertikaals wat weinig te doen het met die mens se horisontale verhouding met die natuur. Hy skryf hierdie siening toe aan 'n neo-Thomistiese skeiding tussen natuur en genade en hy herinner aan die reformatoriese tradisie wat leer dat dit tot die wese van die mens behoort om in 'n verbondsverhouding met God te staan waardeur sy hele lewe - nie net 'n sogenaamde bo-natuurlike sfeer van sy sielelewe nie - religieus bepaald is. Dit het daarom tyd geword dat die skepping weer sy regmatige plek in die Christelike lewensvisie terugvind. Die hele skepping (ook stof, plant en dier) staan in 'n verhouding tot God. Die skepping, wat deur sy woord tot stand gekom het, moet ook antwoord - dit is waarin die sin daarvan lê. Talle natuurgedeeltes in die Skrif maak dit duidelik dat God se skepping hom vreugde verskaf en as't ware 'n kosmiese koor is wat sy lof besing. As een grondstof opgebruik, een stroom opdroog, een plant of dier uitsterf, is hierdie kosmiese koor onvolledig (Van der Walt 2014a:117).

Daar is ook gewys op 'n skeefgetrekte siening oor verlossing wat by baie Christene voorkom. Al te dikwels praat en tree Christene op asof die betekenis van Jesus se vleeswording, dood en opstanding beperk is tot die redding van individuele gelowiges alleen, asof dit iets is wat in die 
lewe hierna buite hierdie geskape wêreld plaasvind (De Klerk 2014a:3). In aansluiting hierby waarsku Conradie (2011:2) oor 'n skeefgetrekte eskatologie waar die mense aan die hiernamaals bloot dink as 'n hemelse verlossing van hierdie "tranedal".

Gebrek aan dienslewering en sanitasie in die Suid-Afrikaanse konteks het uiteraard ook ekologiese konsekwensies. Twee belangrike aspekte waar die kerk in gebreke gebly het om 'n verskil te maak, is uitgewys: die mislukte pogings van kerkleiers in Suid-Afrika by die mediasieproses in die konflik oor dienslewering en die relatief min etiese en teologiese besinning oor sanitasie in Suid-Afrikaanse literatuur (Conradie 2014:12).

Ter versagting word daar gesê dat dit in 'n mate te verstaan is dat die aarde se welstand nie die grootste bekommernis van die kerke in Suid-Afrika was nie. Vir baie jare het politieke bevryding, demokrasie, sosiale versoening en ekonomiese heropbou al die aandag geverg en die agendas tot oorlopens toe gevul (Conradie 2003:122).

\section{Ekologie se plek in die gereformeerde dogma}

\subsection{Kontekstuele teologie}

Ekologie is tradisioneel 'n etiese kwessie, maar verskeie teoloë (soos hieronder aangedui sal word) het die pad van die kontekstuele teologie gekies. Terminologie wat die laaste aantal jare hulle verskyning in die literatuur gemaak het, is "ekologiese teologie" of "eko-teologie" en selfs "skeppingspiritualiteit". Conradie (2005:281) skets die situasie soos volg:

Ecological theology may be regarded as a next wave of contextual theology. It joins liberation theology, black theology, feminist theology, womanist theology and various indigenous theologies in the quest for a theology that can respond to the challenges of our time.

Dit is uiteraard 'n kontroversiële saak. Kroesbergen (2014:1) sê dat dit wil voorkom of diegene wat dit ondersteun en diegene wat dit teenstaan, soms nie in staat is om met mekaar te kommunikeer nie. Daar is sommige teoloë wat nie kan glo dat eko-teologie nie as vak by teologiese fakulteite aangebied word nie, en aan die ander kant is daar teoloë wat die sg. 
"skeppingspiritualiteit" as paganisme beskryf waarteen die kerk ernstig moet waak.

Conradie (2005:281-282) sê egter ter verdediging dat ekologiese teologie nie net begaan is oor hoe die Christendom antwoorde kan gee op omgewingskwessies nie. Dit bied ook die geleentheid vir vernuwing en reformasie. Hy sê ook dat ekologiese teologie nie gereduseer moet word tot omgewingsetiek as 'n sub-dissipline van Christelike etiek nie. Feitlik elke aspek van die Christelike teologie het in elk geval al in ekologiese teologie aandag gekry.

Van Deventer (1996:198) redeneer dat die ekologiese debat op elke teologiese terrein gevoer moet word, maar sê tereg dat daar voorkeur gegee moet word aan eksegetiese studies. Hy waarsku teen hermeneutiese slaggate soos die soeke na "bewystekste", asook kontekstueel bepaalde eksegese waar slegs die konteks van die eksegeet absoluut bepalend is vir die eksegese van 'n perikoop.

\subsection{Ekologie en ander dogmatiese loci}

Ekologie kan in essensie nie van Etiek losgemaak kan word nie, maar ook nie van Dogmatiek nie. Buitendag (2004:412) stel die beginsel duidelik: "Die uniekheid van die Christelike daad is immers altyd tegelyk die uniekheid van die Christelike geloof". Dogmatiese loci wat gereeld te voorskyn tree in studies oor ekologie, is God en sy selfopenbaring, asook die skepping en eskatologie. Van der Walt (2014a:49) maan dat dit nie anders mag nie: "vir 'n deeglike, grondliggende bespreking van ons onderwerp mag 'n mens ... nie net een verhouding - die van die mens tot die natuur - in berekening bring nie. Vir'n Skrifgelowige is mens en natuur immers God se skepping, wat nooit geïsoleerd van die Skepper daarvan beskou mag word nie." Vorster (2007:3) stel dit soos volg in perspektief:

Christian ethical reflection traditionally presupposed a worldview where the existence of the living God as Creator, God and Redeemer-God, the renewal of the world in Christ, the dynamic work of the Spirit and the acceptance of Scripture as normative for life, were seen as the cornerstones. Seen from this traditional perspective it will be fair to say that Christian ethics flows from the revelation of God. In his acts in nature and history, and especially 
in his self-revelation in His Word, God laid down the deepest principles for moral conduct.

Hier word uiteraard gesinspeel op een van die vernaamste vertrekpunte vir die gereformeerde verstaan van die openbaring van God wat in die Nederlandse Geloofsbelydenis, Artikel 2, soos volg verwoord word:

Ons ken Hom deur twee middele: Ten eerste deur middel van die skepping, onderhouding en regering van die hele wêreld ... Al die dinge is genoegsaam om die mense te oortuig en hulle alle verontskuldiging te ontneem. Ten tweede maak Hy Hom deur sy heilige en Goddelike Woord nog duideliker en meer volkome aan ons bekend, en wel so veel as wat vir ons in hierdie lewe nodig is tot sy eer en tot saligheid van hulle wat aan Hom behoort.

Vorster (2016:6-7) is tereg daarvan oortuig dat die klem op die tweeledige openbaring wat op God se algemene genade en voorsienigheid berus en soos wat dit in die reformatoriese tradisie ontwikkel het, steeds werkbaar is as dit gedefinieer word as een openbaring in die skepping, saamgetrek in die Skrif as die geskrewe Woord en verder in die openbaring in Christus as die vleesgeworde Woord. God se een openbaring beweeg van die algemene na die besondere en daarmee saam die verskillende gawes van die Heilige Gees. Mense ontvang skeppingsgawes, gawes wat Calvyn beskryf as 'n "ingegraveerde wet". Die openbaring in die boek van die natuur en die skeppingsgawes van God aan alle mense kan gebruik word as 'n bron vir morele besluitneming in die eko-etiek.

Die Skrif as norm vir die Christen se geloof en lewe is 'n erkende reformatoriese beginsel wat ook in die talle publikasies uit die kerke oor ekologie blyk. Dit moet dus altyd binne die kader van die openbaring verstaan en gehanteer word. "Kenteoretiese uitgangspunte bepaal immers enige werklikheidsverstaan” (Buitendag 2003:1066).

Daar bestaan 'n besondere verhouding tussen God en die skepping wat vir God self groter waarde het as wat ons as mense gewoonlik daaraan toeken. Die skepping het nie alleen via die mens betekenis nie. God se verhouding teenoor die skepping spreek van vreugde, liefde en besorgdheid (Van der Walt 2014a:52). 
Dit blyk ook duidelik uit verskeie studies dat die Goddelike ekonomie van die Drie-eenheid 'n beduidende rol speel as dit kom by ekologiese kwessies. In sy artikel oor Dirkie Smit se trinitariese benadering tot die Teologie, wys Conradie (2003:107) tereg op die onderliggende kwessies as dit kom by die verhouding tussen Christus en die skepping. Dit gaan oor die verhouding tussen Christus en die Heilige Gees, en die verhouding tussen die Vader en die Heilige Gees. Floor (2008:4) herinner aan Calvyn se kommentaar op die brief aan die Efesiërs waar daar op die veelvoudige werking van die Heilige Gees gewys word. Daar is eerstens 'n algemene werking waarin die diere ook hulle aandeel het. In sy kommentaar op Genesis (waar dit oor die skeppingsgebeure gaan) verwys Calvyn weer op die "verborge inspirasie van die Gees van God". Dat ná die sondvloed die waters in die lug, die waters in die oseane en die waters onder die oppervlakte van die aarde nie die wêreld oorstroom nie, is te danke aan die Heilige Gees. Op grond van 2 Petrus 3:10 glo Calvyn dat die Heilige Gees sorg dra vir die stabiliteit in die skepping en in die natuur.

Buitendag (2014:4,9-10) gaan selfs verder en wys op die bruikbaarheid van panenteïsme wat die Duitse idealistiese filosoof Karl Christian Friedrich Krause in 1828 as Allingottlehre gemunt het. God gaan in die skepping in, maar gaan nie daarin óp nie. Panenteïsme is bruikbaar en kan moontlik help om 'n taal te voorsien om sinvol en Bybelgetrou oor God en die wêreld te dink en te praat. Buitendag maan egter tereg: "Getoets binne die Gereformeerde teologie met sy hedendaagse diskoerse wil ek graag gekwalifiseerd sê dit kan, maar dan moet 'n substansie-metafisika verwerp word."

In die teologiese besinning oor ekologiese kwessies speel eskatologie ook'n belangrike rol. Van der Walt (2014a:54) beklemtoon die feit dat die Bybelse toekomsperspektief - anders as wat talle Christene glo en heeltemal anders as byvoorbeeld die Oosterse religieë - baie konkreet en aards is, en voeg by: "Ons is vir hierdie aarde geskep en sal vir dieselfde aarde herskep word, 'n aarde wat self ook vernuwe, herskep sal word. Ons bestemming is nie 'n skaduagtige of engelagtige bestaan in die hemel nie. Dit alles bevestig weer eens hoe belangrik God se skepping hier en nou is!"

Wanneer De Wet (2014:2) oor die profetiese taak van die kerk praat, sê hy dat dit in die DNS van 'n profeet lê om die herstellende genade van God te 
bedien te midde van 'n konteks wat gekenmerk word deur skeefgetrekte verhoudings. Deur hierdie bediening word die daarstel van 'n nuwe hemel en aarde geantisipeer. Van Tonder \& Tucker (2014:4) gee ook toe dat, hoewel 'n herstelproses op elke moontlike front deur Christene bevorder moet word, daar aanvaar sal moet word dat die verwoesting wat veroorsaak is uiteindelik met die laaste Sabbat van die wederkoms eskatologies herstel sal word, wanneer alles nuut gemaak sal word.

\section{Ekologie en sosiale geregtigheid}

Die kwessie van "ekologiese geregtigheid" of "omgewingsgeregtigheid" het maar onlangs in publikasies begin verskyn (Bedford-Strohm 2013:27). Dit is 'n kombinasie van ekologie en sosiale geregtigheid. Conradie (2003:127) verduidelik dit so:

... "eco-justice" refers to the interlocking web of concern about the earth's carrying capacity, its ability to support the lives of its inhabitants and the human family's ability to live together in harmony. It highlights the interrelatedness of such pressing issues such as world hunger and world peace, the energy crisis and unemployment, appropriate technology and good work, biblical stewardship and feminist consciousness, radical justice and pluralistic community, lifestyle choices in response to poverty and pollution.

Ter wille van die omgewingsbewustheid by alle Suid-Afrikaners is dit van uiterste belang om tot die besef te kom dat baie van die omgewingsprobleme wat ondervind word, nou verweef is met die probleme wat die armes en gemarginaliseerdes in Suid-Afrika elke dag ervaar. Hoewel die agteruitgang van die omgewing alle mense affekteer, gebeur dit tog nie in gelyke mate nie. Dit word al hoe meer erken dat die slagoffers van omgewingsagteruitgang ook die slagoffers van sosio-ekonomiese ongeregtigheid is. Dit is soms moeilik om omgewingsake en politiek in Suid-Afrika van mekaar te skei (Conradie 2003:126-127).

Vroue word veral geïdentifiseer as besondere slagoffers van omgewingsvernietiging en Ackerman (1997:52) wys daarop dat vroue die eerste was wat in opstand begin kom het teen omgewingsvernietiging. Sy verwys in 
hierdie verband na "eko-feminisme" as term wat, volgens haar, relatief onbekend is en verkeerd verstaan word. Uiteraard moet daar ook in gedagte gehou word dat die Grondwet van Suid-Afrika in Artikel 24 onder andere bepaal dat elkeen die reg het op 'n omgewing wat nie skadelik vir hul gesondheid of welsyn is nie.

Boesak et al. (2010:52-53) wys daarop dat ekologiese onreg ook die verlies aan vryheid vir talle mense vandag en in die toekoms beteken. Dit kan daarom nie los gemaak word van die Bybelse norm van liefde nie. Liefde as 'n politieke norm het twee kante: Deernis en geregtigheid en liefde as 'n polities-ekologiese norm het 'n derde kant - die welsyn van die aarde. Hy sluit sy argument soos volg af: "This is our complete worship of God, and our complete commitment to human and ecological justice, as we work with God and pray for God's Holy Spirit to come and renew the face of the earth (Ps 104:30).”

\section{Ekologie in die amptelike besluite van die gereformeerde kerke in Suid-Afrika}

\subsection{Inleiding}

Die drie Afrikaanse gereformeerde kerke in Suid-Afrika is al sedert 1943 in gesprek oor kerkeenheid en gemeenskaplike sake binne die gestigte Tussenkerklike Raad (TKR). In 2005 het hierdie raad 'n verklaring uitgereik waarin die oortuiging uitgespreek word dat die kerke binne die Suider-Afrikaanse gemeenskap(pe) moet help om 'n grondige debat oor 'n stel morele waardes vir die samelewing aan die gang te kry. 'n Aantal lewensterreine word geïdentifiseer waarop die waardes ontwikkel moet word. Daaronder tel armoede en die ekonomiese stelsels binne gemeenskappe, arbeid, die ekologie, die basiese boustene vir 'n gemeenskap (bv. familie) en multikulturaliteit. Die TKR en die verteenwoordigde kerke het hiermee hulleself bereid verklaar om inisiatief te neem in die totstandkoming van sodanige gesprekke (GKSA 2006:182).

Op mindere vergaderings van die kerke en in plaaslike gemeentes is uiteraard ook aandag aan die saak van ekologie gegee, maar omdat dit meestal in die meerdere vergaderings uitkristalliseer, word hier slegs aandag aan die besluite daaroor op nasionale en algemene sinodes gegee. 


\subsection{Die Nederduitse Gereformeerde Kerk (NGK)}

Die Sinodale Kommissie vir Leer en Aktuele Sake het in opdrag 'n verslag met aanbevelings by die Sinode van 1998 laat dien waarin erken word dat die NGK nog nooit amptelik by ekologiese kwessies betrokke geraak het nie en selfs vir baie jare van dit wat op ekumeniese terrein ten opsigte van ekologiese vraagstukke gedoen is, geïsoleer is. Daar word onomwonde erken dat daar 'n ekologiese krisis heers en dat dit veral op die terreine van bevolkingsgroei en industrialisasie manifesteer. Die hoogmoed en arrogansiekarakter van die sonde word op min ander terreine so duidelik gesien as daar waar die mens hom aan die goeie skepping van God vergryp. Die Kommissie wys ook daarop dat die mens deel is van die skepping wat bewaar en gekoester moet word. Dit is daarom ondenkbaar dat 'n mens teen iets kan wees waarvan jy integraal deel is. Daar word ook gekyk na wat heerskappy oor die skepping werklik beteken. Die verslag roep die kerk op om verantwoordelikheid te aanvaar, omdat 'n verskraalde evangelie 'n belangrike rol gespeel het in die aanbring van die ekologiese krisis en wys daarop dat die kerk deur die verkondiging van die omvattende evangelie lidmate sensitief moet maak vir die ekologiese dimensie van die evangelie (NGK 1998:54-57).

By dieselfde sinode is 'n beroep gedoen op leraars om deur prediking en ander toerustingsgeleenthede lidmate steeds bewus te hou van hulle versorgingstaak in die wêreld. Daar is ook by kerke aanbeveel om by geskikte geleenthede soos Pinkster en Internasionale Aardedag besondere aandag te gee aan die implikasies van die evangelie vir die ekologie en om gemeentes die geleentheid te bied om "tydens lofprysingseredienste rondom die Woord en met die kerklied in verootmoediging, aanbidding en lofverheffing voor die aangesig van die Here te verskyn" (NGK 1998:179).

In 'n roepingsverklaring wat by die Algemene Sinode van 2004 uitgereik is, bevestig die Sinode die kerk se verbintenis tot Afrika as kontinent, in die besonder Suider-Afrika, en spreek sy ontsteltenis uit oor, onder andere, die gebrek aan respek vir mense, diere en die omgewing en ook die kerk se aandeel daaraan (NGK 2004:24).

Onbeheerste ekonomiese groei in ontwikkelde lande word geïdentifiseer as 'n bedreiging vir die omgewing en die bereidwilligheid om met ander kerke saam te werk rondom ekologiese kwessies, word duidelik gestel 
(NGK 2007:112-113). Globalisering en die effek daarvan op die mens en die ekologie is ook as 'n prioriteit geïdentifiseer (NGK 2011:110, 162).

Dit is opmerklik hoe daar sedert 2013 al hoe meer praktiese maatreëls deur die sinodes in werking gestel word om die ekologiese krisis op grondvlak aan te pak. In 2013 word die dokument, Ter wille van die aarde en haar bewoners, as 'n raamwerkdokument aanvaar (NGK 2013:48) en in 2015 word verwys na nuut-ontwikkelde materiaal om die saak van die ekologie in die gemeentes te bevorder. Bepaalde aktuele kwessies soos hidrokraking, kernkrag en hernubare energie kry aandag en opdrag word gegee om die moontlikhede van disinvestering in enige ekologies-onvriendelike beleggings te ondersoek. Die aanslag teen die krisis neem ook 'n meer ekumeniese karakter aan. Daar is nou ook 'n oproep tot gesprek met ander geloofsgroeperinge en nie-kerklike organisasies en die Algemene Sinode neem met dank en waardering kennis van Pous Franciskus se ensikliek, Laudato Si, van 24 Mei 2015 met die subtitel, Ons gemeenskaplike woning (NGK, 2015:71).

\subsection{Die Nederduitsch Hervormde Kerk van Afrika (NHKA)}

By die opening van die 71ste Algemene Kerkvergadering van die NHKA op Sondag 2 Oktober 2016 word die HCM Fourie-erepenning aan prof. Johan Buitendag oorhandig. Hy was van die eerste teoloë in Suid-Afrika om vanuit teologiese perspektief na die kwessie van ekologie te kyk. By die ontvangs van hierdie toekenning gee hyself soos volg 'n oorsig van sy werk:

Ek het my ook met veral twee natuurwetenskaplike dissiplines besig gehou: Fisika en biologie. Fisika was vir my belangrik om tyd en ruimte te verstaan, en biologie om meer uit te vind oor evolusie. My proefskrif ${ }^{1}$ het oor skepping en ekologie gehandel, en reeds daar het ek die kontoere ontdek van 'n teologies verantwoordbare werklikheidsverstaan. Die Twaalf Artikels plaas die skepping by die werk van die Vader. Karl Barth het dit Christologies uitgelê, terwyl dit vir mý duidelik was dat ons pneumatologies oor die skepping

1 "Skepping en Ekologie: 'n Sistematiese ondersoek na die teologiese verstaan van die werklikheid", wat hy in 1985 aan die Universiteit van Pretoria geskryf het vir die verwerwing van die graad Doctor Divinitatis in Sistematiese Teologie. 
moet besin. Daarom het Gijs Dingemans se pneuma-teologie by my byval gevind (NHKA 2016b: 26).

By die 70ste Algemene Kerkvergadering in 2013 het die Raad vir Gesinsbediening 'n rapport voorgelê oor kategese beplanning. In die voorgestelde lesmateriaal kry ekologie 'n prominente plek en word die volgende onderwerpe ingesluit: besoedeling, bewaring en hersirkulering (NHKA 2013:624 en 632).

Die NHKA het die kwessie van ekologie ook aan Missionale Bediening gekoppel. Daar word gewys op die heersende tegnokratiese benadering tot die werklikheid waarmee daar gepoog word om die totale werklikheid te manipuleer, te beheer en te misbruik. Die gevolg is dat daardie deel van die werklikheid wat nie gemanipuleer en beheer word nie, eenvoudig ontken word. Om hierdie rede word die lewensbenadering tot net een dimensie van bestaan vervlak, naamlik produksie en verbruik, terwyl die werklikheid 'n groter rykdom van moontlikhede bied. Die volgende waarskuwing word gerig: "In die toekoms sal ons ons eensydige benadering tot die werklikheid moet korrigeer. Doen ons dit nie, sal die ekologiese krisis wat ons tans begin beleef oor ons die oorhand kry" (NHKA 2016b:707). Tweedens word gewys op die effek van die verskynsel van die sogenaamde. "global village": "'n Lekkasie van olie uit 'n boorgat in die Golf van Mexiko is nie net die Amerikaners se probleem nie, maar het implikasies vir die hele wêreld. Renosters wat in Suid-Afrika uitgeroei word sodat Oosterlinge hulle horings in die hande kan kry, is 'n voorspel tot 'n ekologiese krisis wat wêreldwyd buite beheer raak" (NHKA 2016b: 725).

Omdat Dordt in Hervormde teologie nooit met dieselfde passie bely is as in die Gereformeerde Ortodoksie nie (NHKA, 2016a:91), is daar op versoek van die Algemene Kerkvergadering verskeie studiestukke oor die Dordtse Leerreëls deur teoloë van die Kerk voorberei. Daar word in een van hierdie verslae gewys op die waarde van die volgehoue behoud van die Dordtse Leerreëls om die kerk skerper te laat verstaan hoe futiel, onder andere, selfverryking is wat ondersteun word met eksploitasie van mense se ekologiese en sosiale ruimtes (NHKA 2016a:845). 


\subsection{Die Gereformeerde Kerke in Suid-Afrika (GKSA)}

Die kwessie van ekologie het vir die eerste keer in 2003 vanuit twee hoeke op die tafel van die Nasionale Sinode van die GKSA gekom. Die eerste is in die vorm van 'n verslag oor die kwessie van immigrasie en die inburgering van immigrante. Kruiskulturele kwessies word uitgewys as die grootste oorsaak waarom inburgering van immigrante nie altyd slaag nie. Die volgende kwessies word geïdentifiseer: volwasse opvoeding, jeugwerk, maatskaplike werk, kultuurwerk, omgewingsbewustheid/-bewaring en godsdienssonde (GKSA 2003:228). Tweedens het die Deputate vir Christelike Onderwys 'n uitgebreide opdrag ontvang om deskundiges te koöpteer vir kurrikulering en onderrigmateriaal om lesmateriaal en handboeke vanuit gereformeerde lewens- en wêreldbeskouing te skryf. Daar was konsensus dat alvorens daar lesmateriaal ontwikkel kan word, daar eers 'n kernkurrikulum ontwikkel moes word. 'n Volledige kernkurrikulum vir Bybelonderrig vir Gr. 1-12 is saamgestel en sluit die volgende in: Openbaringsgeskiedenis, Kerkgeskiedenis, Geloofsleer, Kanoniek, Bybelse omgewingsleer, Etiek en bespreking van hedendaagse godsdienstige strominge (GKSA 2003:418).

Teen 2006 het grondhervorming in Suid-Afrika 'n aktuele kwessie geword en die Nasionale Sinode het dit ter tafel geneem. Die Sinode het gemaan dat by grondhervorming daar met ekologiese oorwegings rekening gehou moet word. Ekologiese krisisse moet voorkom word deur faktore soos oorbevolking, oorbeweiding, gronderosie, ontbossing en omgewingsbesoedeling (GKSA 2006:833).

Die Algemene Sinode van 2012 het'n beskrywingspunt van die Streeksinode Noordwes oor omgewingsake behandel en belangrike besluite geneem. Die Sinode het uiteindelik 'n "Openbare getuienis oor die ekologiese krisis vanuit Suid-Afrika”, die lig laat sien. Die eerste deel van hierdie getuienis is 'n belydenis oor God as die groot Eienaar en Regeerder van sy skepping, die mens se opdrag en rol daarin, die negatiewe gevolge van die mens se gebroke verhouding met God, die nuwe begin wat God in Christus met die stukkende wêreld gemaak het, en die belofte van 'n nuwe skepping, onder andere. In die tweede deel van die getuienis word 'n diep besorgdheid uitgespreek oor ongebreidelde bevolkingsaanwas, die onhoudbare druk op die aarde se beperkte hulpbronne, die toenemend-onvolhoubare vlakke van uitbuiting en besoedeling van die biosfeer, atmosfeer en 
hidrosfeer, die vernietiging van die omgewing ter wille van eie gewin, en die uiters oneweredige verspreiding van welvaart op aarde. Daar word in besonder aandag gegee aan die situasie in Suid-Afrika en kwessies soos die groot koolstofvoetspoor, die onvolhoubare uitbuiting van ons mariene hulpbronne, die verswakkende watergehalte in ons riviere, die toenemende besoedeling van ons grond deur elektroniese-, mediese-, huishoudelike-, industriële- en mynafval, erosie van kosbare landbougrond en die skynbare onvermoë van leiers om die onvolhoubare gaping tussen ryk en arm te verklein. Die derde deel van die getuienis bevat 'n oproep aan die inwoners, maatskappye, nywerhede, regerings, godsdiensgroepe en kerke in die wêreld om 'n totale mentaliteitsverandering te ondergaan waarin groter waardering en sensitiwiteit vir die omgewing as skepping van God ontwikkel word, om duidelik standpunt in te neem en verantwoordelikheid ten opsigte van die omgewing na te kom. Kwessies wat ook verder uitgelig word, is, onder andere, die verpakking van produkte, die uitfasering van plastiek as verpakkingsmateriaal, en mensgedrewe klimaatsverandering (GKSA 2012:512-513).

Die Sinode van 2018 het hierdie getuienis herbevestig en besluit om van "omgewingsake" eerder as ekologie te praat, omdat dit in die getuienis om meer as net ekologie gaan. Praktiese maatreëls is ingestel om hierdie saak onder die lidmate se aandag te bring deur middel van die GKSA se webwerf, Facebook en e-posse aan gemeentes, en artikels in die kerklike tydskrifte. Daar is met dankbaarheid kennis geneem dat die beskrywingspunt en deputatewerksaamhede tot gevolg gehad het dat daar 'n module, Omgewingsetiek, vir vierdejaar teologiese studente by die Teologiese Skool Potchefstroom ingestel is (GKSA 2018:1015-1017).

\subsection{Die Verenigende Gereformeerde Kerk in Suider-Afrika (VGKSA)}

Op 14 April 1994 het die NG Sendingkerk met die NG Kerk van Afrika saamgesmelt om die VGKSA te vorm. Tussen die jare 1994 en 2002 het kwessies rondom hierdie samesmelting en die gepaardgaande hofsake die agenda oorheers. Dit het betrokkenheid by ekologiese kwessies in 'n mate op die agtergrond geskuif. Vroeg in 2002 het die momentum egter weer opgebou.

'n Kommissie vir Omgewingsorg van die NG Kerk en die VGKSA in Kaapland is egter al in 1995 deur die Kommissie vir Getuienisaksie (KGA) 
in die lewe geroep met die doel om die kerk op die hoogte te bring van die omvang van ekologiese probleme in Suid-Afrika, die kerk bewus te maak van sy rentmeesterskap teenoor die skepping en om die kerk te bedien met praktiese riglyne oor hoe lidmate en gemeentes sinvol by hierdie aksies betrokke kan raak.

In 2005 is daar 'n rapport van die VGKSA se United Ministry for Service and Witness (UMSW) by die Vyfde Algemene Sinode ingedien. 'n Deel van die rapport bevat 'n verklaring van die algemene sekretaris van die All Africa Conference of Churches (AACC) wat by geleentheid van Wêreld Omgewingsdag vrygestel is. ${ }^{2}$ Bogenoemde verklaring begin met die volgende stelling: "Climate change crisis is primarily spiritual and ethical and therefore the church and other faith communities must uphold the dignity and livelihoods of the effected." Daar word besondere klem gelê op die verwoestende effek wat aardverwarming op Afrika het. 'n Belangrike voorstel wat gemaak is, is dat kerke moet toesien dat omgewingsake 'n integrale deel vorm van die curricula van die teologiese opleiding van hulle predikante. Daar word veral 'n beroep gedoen op geloofsgemeenskappe in die noorde van Afrika om druk toe te pas op hulle regerings om hulle "koolstofskuld" te betaal, daadwerklike stappe te doen om $\mathrm{CO}^{2}$-vrystelling te beperk en die aanpassingsinisiatiewe van die suide te ondersteun. Kerke word ook aangemoedig om die owerhede te oorreed om toepaslike wetgewing en beleidsraamwerke daar te stel (VGKSA 2005:306-307). Die Sinode (2005:284) neem vervolgens drie belangrike besluite op grond van hierdie rapport: Dat die streeksinodes en gemeentes betrokke sal raak by omgewingskwessies, dat voortgesette studie gedoen moet word oor genetiese manipulasie en dat die Sinode deur bogenoemde kommissie iemand sal aanwys om 'n beleidsdokument op te stel oor kernkragkwessies in Suid-Afrika.

As lede van die World Alliance of Reformed Churches (WARC), het die VGKSA saam met die Evangelisch Reformierte Kirche in Duitsland deelgeneem aan die sogenaamde. Globalisation Project en in 2010 'n uitgebreide rapport die lig laat sien waarin ekologiese verantwoordelikheid

2 Hierdie herdenkingsdag is in 1972 deur die Algemene Vergadering van die Verenigde Nasies ingestel en word jaarliks gevier. Suid-Afrika was in 1995 die gasheerland vir die wêreldwye viering hiervan (VGKSA 1995:306). 
'n belangrike plek inneem. Sake wat aandag geniet, is onder andere klimaatsverandering, aardverwarming, voedsel- en waterkrisisse, die (oor) benutting van energiebronne en die negatiewe invloed daarvan op die samelewing en die uitdagings daarvan vir die Christelike kerke. Die vraag word gevra of verbruikersmanie nie as 'n afgodsdiens, voorspoedsgodsdiens en 'n dwaalleer beskryf moet word nie, juis in die lig van die verwoestende effek wat dit op die aarde se ekologie het (Boesak et al 2010:44-45).

In 2012 het die Sesde Algemene Sinode van die VGKSA in die lig van Psalm 24 'n belydenis geformuleer dat die kerk en die mensdom die verantwoordelikheid teenoor die aarde en alles wat daarop lewe, misverstaan en die skat wat God gemaak het, wanbestuur. Daar word gewys op 'n gebrek aan die waardering van God se heerskappy oor die aarde, 'n gebrek aan geloofwaardigheid as dit kom by die versorging van die aarde en sy bewoners en 'n gebrek aan liefde vir mekaar wanneer daar so in die omgewing opgetree word dat mense se gesondheid bedreig word. Die Sinode besluit ook om duidelik standpunt in te neem teen hidrokraking in die Karoo, 'n kwessie wat via die tafel van die Ring van Graaff-Reinet op die sinode-tafel gekom het. Die Sinode is dit met die Ring eens dat dit katastrofiese gevolge vir die omgewing mag hê soos wat elders in die wêreld die geval was. Daar word vervolgens besluit dat daar 'n behoorlike wetenskaplike studie gedoen moet word op grond waarvan die kerk 'n getuienis daaroor kan laat hoor. Daar word ook 'n beroep gedoen op al die lidmate van die VGKSA om onverskrokke en onophoudelik te getuig ten gunste van omgewingsgeregtigheid in Suidelike Afrika en die wêreld (2012:229-230).

\section{Oplossing van die krisis}

In die meeste van die studies deur teoloë en sinodebesluite van die gereformeerde kerke in Suid-Afrika wat geraadpleeg is, word daar oplossings vir die ekologiese krisis voorgestel. Die profetiese taak van die kerk word telkens beklemtoon. Bedford-Strohm (2013:33) bepleit "inclusive prophetism" as deel van die kerk se modus operandi om omgewingstransformasie teweeg te bring. Profetiese optrede en dialoog is nodig, want albei het verskillende rolle te speel. Die profetiese optrede van die kerk moet gebaseer wees op Bybelse waarhede en goeie argumente 
as dit by openbare diskoers kom. Van Tonder \& Tucker (2014:7) bepleit dieselfde modus operandi in die kwessie van hidrokraking in die Karoo:

In a democracy such as South Africa, where politicians make the decisions concerning fracking, and are probably influenced by shortterm considerations, concerned Christians must endeavour to make sense of the basic facts in order to exercise an informed influence.

Daar word dikwels 'n oproep gedoen vir 'n meer eenvoudige lewenstyl wat minder druk sit op die omgewing. Dit moet ook verstaan word teen die agtergrond van die klassieke Christelike deugde van matigheid, selfbeheersing en eenvoud. Die evangelie vra nie 'n afkeer van dit wat aards, liggaamlik of materieel is nie. Dit bevestig die besondere waarde van die skepping en vind vreugde in die oorvloedige gawes wat God gee (Conradie \& Pauw 2002:418-419). Temas rondom die omgewing en leefstylverandering moet deel gemaak word van die liturgie, kategese en ander vorme van gemeentewees (NGK 2013:48).

Die twee vernaamste elemente in die erediens wat hiervoor aangewend kan word, is lofprysing of doksologie en die belangrike teenpool daarvan, sang en gebed - veral treurgebede en skuldbelydenis. Dit beteken dat gelowiges die skoonheid en waardigheid van alle lewe vier en ook getuienis lewer van die skepping wat sug onder die lyding van ekologiese verwoesting. Dit sal ook lei tot 'n liturgiese getuienis van God wat nuut maak en die siklus van selfvernietiging verbreek. De Klerk (2014a:1;2014b:9) wys byvoorbeeld op beginsels wat uit Psalm 148 na vore kom. Deelnemers aan die erediens word opgeroep om God te prys vir sy skepping in alle liturgiese gebeure. Die feit dat hierdie oproep om God te prys aan die hele skepping gerig word, behoort die gemeente op te roep om die hele skepping te vier. Daar bestaan 'n besondere simbiose tussen die viering van die mens en die res van die skepping. Onsensitiwiteit wat ekologie betref het ook 'n negatiewe invloed op die liturgie van die gemeente.

De Wet (2014:5-7) het 'n studie van die Pauliniese gedeeltes in die Bybel gemaak waar gelowiges opgeroep word om die gesindheid van Christus te openbaar, hulle aan die wil van die Vader te onderwerp en om die gesindheid van 'n slaaf aan te neem. Hy pas dit toe op die hantering van die ekologiese krisis in Suid-Afrika, veral die uitdagings wat vullisstorting vir die mens inhou. Wanneer hulle wat naby stortingsterreine leef, siekte en dood 
ervaar wat grootliks veroorsaak word deur die rommel en toksiese afval van ander, sal hulle, as hulle die gesindheid van Christus openbaar, dit in die gesig staar met die hoopvolle gebed dat hulle eie broosheid 'n getuienis teenoor die mensdom sal word oor die gevolge van hulle optrede. Dit sal 'n getuienis wees dat die mensdom nie kan voortgaan om 'n oorvloed afval te produseer asof dit iets is wat onder die mat gevee en vergeet kan word nie. Wanneer hulle wat bevoordeel word deur die verbruikersmaniese sisteem begin om hulle lewens vir die gesindheid van Christus oop te maak, sal dit vir hulle ondraaglik begin word om verder saam te leef met onreg wat hulle eie oordaad aan ander mense veroorsaak. Hulle sal ook begin insien dat alle mense kosbaar is in die oë van die Here en dat hulle wat ly onder die afval van ander 'n grootse teater is om ons te herinner dat die mensdom slegs deur die genade van God kan leef en dat ons ons ware medemenslikheid kan beleef as ons daardie genade bedien aan die minste onder ons.

Vanuit 'n teologiese hoek word 'n beroep op Praktiese Teologie gedoen om betrokke te raak by die vasteland se ekologiese uitdagings. 'n Groter poging word bepleit om die metode en bevindings van hierdie teologiese vakgebied in 'n taal te kommunikeer wat op grondvlak deur Christene verstaan en toegepas kan word (Van Tonder \& Tucker 2014:1).

'n Interessante oplossing wat ook aangebied word, is 'n oproep tot die internalisering van 'n nuwe stel morele reëls wat die mensdom se gewaande reg om lewe te verleng wat nie lewensvatbaar is nie, uit te daag omdat dit tot die nadeel van die natuur en die mensdom in die algemeen geskied. (Van der Walt 2016:7).

By al die kerke het die besef spoedig deurgedring dat individue en individuele kerke nie alleen hierdie krisis kan aanpak nie. Om hierdie rede word daar gedurig 'n oproep gedoen dat daar tussen die gereformeerde kerke, maar ook ekumenies en met ander geloofsgroeperinge en nieregeringsorganisasies gesprekke moet kom ten einde die bewaring van die omgewing te bevorder.

\section{Slot}

Dit is opvallend dat die kwessie van ekologie in die bestek van slegs enkele jare, naamlik in die negentigerjare van die vorige eeu, op die agendas van 
die sinodes van die gereformeerde kerke in Suid-Afrika verskyn het. Daar is ook 'n gemeenskaplike ontwikkeling in die debat te bespeur en drie fases kan geïdentifiseer word. Aanvanklik was daar die erkenning dat daar 'n krisis is en dat die kerk aandadig is, veral as gevolg van skeefgetrekte teologiese uitgangspunte en 'n gebrek aan openbare optrede. Skuldbelydenis en belydenis van 'n suiwerder siening van die skepping en die mens se verhouding tot God het gevolg. Meer onlangs het die debat "grond gevat" in praktiese bydraes om op voetsoolvlak die lidmate van die kerke te bemagtig om 'n verskil in hulle samelewing te maak. Hierdie laaste fase is ook gekenmerk deur die identifisering van bepaalde konkrete kwessies soos hidrokraking, vullisstorting, waterbesoedeling, plastiekherwinning, ens.

Hoewel die gereformeerde kerke in Suid-Afrika se getalle drasties krimp en hoewel daar baie kritiek teen die impak van die kerke op die samelewing is (kyk Dreyer 2016:1-9) en ten spyte daarvan dat daar eers op 'n laat stadium tot die stryd teen omgewingsverwoesting toegetree is, het die kerke 'n beduidende wye trefwydte wat ouderdom, ras, geslag en sosiale status betref. Deur teologiese besinning, teologiese opleiding, die opvoeding van die jeug, liturgiese inkleding, prediking en gemeenteprojekte is daar reeds 'n aansienlike impak op die samelewing gemaak. Die aandrang op 'n eenvoudiger lewe, 'n meer verantwoordelike omgang met die skepping en morele hervorming is kwessies wat reeds 'n verskil gemaak het. 'n Groter invloed op regeringsinstansies en groter ekumeniese samewerking met ander plaaslike en internasionale kerke is egter nog nodig. Wat laasgenoemde betref is die VGKSA hier 'n voorbeeld vir die ander kerke (kyk PlaatjiesVan Huffel 2013:1). Die kerke en hulle teoloë het talle oplossings aan die hand gedoen. Dit is dringend noodsaaklik dat dit deurgevoer moet word. Die oproep tot semper reformanda is ook van toepassing as dit kom by die opdrag om die skepping te bewoon, te bewerk en met verantwoordelikheid en wysheid daaroor te heers. Die tyd is besig om uit te loop.

\section{Bibliografie}

Ackerman, D. 1997. Earth-healing in South-Africa: challenges to the church. Ecotheology, 2:48-58. 
Bedford-Strohm, H. 2013. Poverty, wealth and ecology - A theological perspective. Nederduitse Gereformeerde Teologiese Tydskrif, 54(3\&4):24-36.

Buitendag, J. 1988. En nou bly Skepper, skepsel, skepping - hierdie drie: 'n Teologiese profiel van die ekologiese debat. Hervormde Teologiese Studies, 44(2):295-313.

Buitendag, J. 2003. Die wêreld as gelykenis: 'n Trajek om die middelterm van die "teologie" te vind. Hervormde Teologiese Studies, 59(4):10631080 .

Buitendag, J. 2004. Anders dink anders doen. Op soek na 'n ekoteologiese perspektief op kloning. Verbum et Ecclesia, 25(2):402-422.

Buitendag, J. 2014. Panenteïsme as 'n funksionele, induktiewe konstruk in die gesprek tussen die teologie en die (natuur)wetenskap. Verbum et Ecclesia, 35(2), Art. \#879. http://dx.doi.org/10.4102/ve.v35i2.879. 1-11.

Boesak, A., Weusmann, J. \& Amjad-Ali, C. (eds). 2010. Dreaming a Different World. Globalisation and Justice for Humanity and the Earth - The Challenge of the Accra Confession for the Churches. Stellenbosch: The Globalisation Project.

Conradie, E. 2003. How can we help to raise an environmental awareness in the South African context? Scriptura, 82:122-138.

Conradie, E. 2006. Waar op dees aarde vind mens God? Op soek na 'n aardse spiritualiteit. Wellington: Lux Verbi.BM.

Conradie, E. 2011. Christianity and earthkeeping. In search of an inspiring vision. Stellenbosch: Sun Press.

Conradie, E. 2013. On Jesus Christ as Mediator of creation. Nederduitse Gereformeerde Teologiese Tydskrif, 54(3\&4):105-116.

Conradie, E. 2014. From land reform to poo protesting: some theological reflections on the ecological repercussions of economic inequality. Scriptura, 113 (1):1-16.

Conradie, E. \& Pauw, J. (2002). Dialogiese, ekologiese en teologiese perspektiewe ten opsigte van 'n verbruikerskultuur (“consumerism”). Nederduitse Gereformeerde Teologiese Tydskrif, 43(3\&4):407-422. 
Conradie, E. \& Field, D. 2016. A rainbow over the land. Equipping Christians to be earthkeepers. Wellington: Biblecor.

De Klerk, B. 2014a. Enhancing ecological consciousness through liturgical acts of doxology and lament. Verbum et Ecclesia, 35(2), Art. \#859. http://dx.doi.org/10.4102/ve.v35i2.859. 1-8.

De Klerk, B. 2014b. The power of praise psalms to encourage awareness ofecological issues amongst worshippers. Luce Verbi 48(2), Art. \#1689. http://dx.doi.org/10.4102/ids.v48i2.1689. 1-9.

De Wet, F. 2014. Renewal according to the mind of Christ as trigger for prophetic action in dealing with human waste. HTS Teologiese Studies/Theological Studies, 70(2), Art. \#2630, http://dx.doi. org/10.4102/hts.v70i2.2630.1-8.

Dreyer, W. 2016. Praktiese ekklesiologie - Kerkwees in die 21ste eeu. HTS Teologiese Studies, Supplementum 10. Durbanville: AOSIS.

Floor, L. 2008. Die Gees van God maak die aarde nuut. Die Kerkblad, Mei: $4-5$.

Gereformeerde Kerke in Suid-Afrika. 2003. Handelinge van die agt-en-veertigste Nasionale Sinode. 6 Januarie en volgende dae. Potchefstroom.

Gereformeerde Kerke in Suid-Afrika. 2006. Handelinge van die nege-en-veertigste Nasionale Sinode. 4 Januarie en volgende dae. Potchefstroom.

Gereformeerde Kerke in Suid-Afrika. 2012. Handelinge van die tweede Algemene Sinode van die Gereformeerde Kerke in Suid-Afrika. 4 Januarie en volgende dae. Potchefstroom.

Gereformeerde Kerke In Suid-Afrika. 2018. Handelinge van die vierde Algemene Sinode. 9 Januarie en volgende dae. Potchefstroom.

Koegelenberg, R. (red.). 2002. The Land is crying for Justice. A discussion document on Christianity and Environmental Justice in South Africa. Stellenbosch: EFSA. 
Kroesbergen, H. 2014. Ecology: Its relative importance and absolute irrelevance for a Christian: A Kierkegaardian transversal space for the controversy on eco-theology. HTS Teologiese Studies, 70(1), Art. \#2719, http://dx.doi.org/10.4102/hts.v70i1.2719. 1-8.

Nederduitsch Hervormde Kerk van Afrika. 2016a. Agenda van die 71ste Algemene Kerkvergadering, 2 - 7 Oktober 2016, Pretoria.

Nederduitsch Hervormde Kerk van Afrika. 2016b. Notule van die 71ste Algemene Kerkvergadering, 2 tot 7 Oktober 2016, Pretoria.

Nederduitse Gereformeerde Kerk. 1986. Notule van die sewende vergadering van die Algemene Sinode. 14 Oktober en volgende dae. Kaapstad: sn.

Nederduitse Gereformeerde Kerk. 1998. Handelinge van tiende vergadering van die Algemene Sinode. 11 - 17 Oktober. Pretoria:sn

Nederduitse Gereformeerde Kerk. 2004. Inhoudelike notule van die Twaalfde Algemene Sinode. 10 - 16 Oktober. Hartenbos:sn.

Nederduitse Gereformeerde Kerk. 2007. Handelinge van tiende vergadering van die Algemene Sinode. 4 - 8 Junie. Boksburg:sn.

Nederduitse Gereformeerde Kerk. 2013. Notule vir die vyftiende vergadering van die Algemene Sinode. 6 - 10 Oktober. Port Elizabeth:sn.

Plaatjies-Van Huffel, M. (2013). The search for common understanding with regard to ecology and justice in the Uniting Reformed Church in Southern Africa. Studia Historiae Ecclesiasticae, 39 (2).

Stander, H. 2001. Christene moet ook besorg wees oor die aarde (en nie net oor die hemel nie). In P. Meiring, (red.) So glo ons. Gelowig nagedink oor God, die Bybel en ons leefwêreld. Vereeniging: CUM. $155-169$.

Van Aarde, A.G. \& Van Wyk, T. 2014. Teologie as werklikheidsverstaan anders dink, anders doen: Aantekeninge oor die teologie van Johan Buitendag. HTS Teologiese Studies, 70(1), Art. \#2823, 14 bladsye. http://dx.doi.org/10.4102/hts.v70i1.2823

Van der Walt, B. 2014a. Ekologiese perspektiewe uit die Bybel. Woord en Daad, 53 (4\&5): 49-54. 
Van der Walt, B. 2014b. 'n Probleem-historiese analise van die neoThomistiese wetenskapsbeoefening. 'n Verklaring van die denkrigting se veranderende visies op die verhouding tussen natuur en genade. Tydskrif vir Christelike Wetenskap, 1:101-122.

Van der Walt, C. 2016. Humanity's perceived right to life and the impact thereof on the environment: A perspective from Deuteronomy 20:19-20. In die Skriflig, 50(4), a2079. http://dx.doi.org/10.4102/ids. v50i4.2079. 1-7.

Van der Walt, I. 2005. Bewoon, bewerk, heers oor (verwoes) die aarde. Die Kerkblad. Sep: 18-21.

Van Deventer, H. 1996. 'n “Groen” Israel - ekologiese rigtingwysers uit Levitikus 25:1-7? In die Skriflig, 30(2):185-201.

Van Hamburg, H. 2008. Die openbaring van God in die wonder van ekosisteme. Die Kerkblad. Mei: 28-28.

Van Tonder, G. \& Tucker, R. 2014. "Karoo fracking and the Christian faith community." HTS Teologiese Studies 70(2), Art. \#2631, http:// dx.doi. org/10.4102/hts.v70i2.2631. 1-8.

Van Wyk, J. 2015. Die ekologiese krisis. Die Kerkblad, Sept: 12-14.

Venter, P. 2009. Die vrou Wysheid, God, en ekobillikheid:

Liggaamsideologie in Spreuke 8:1-9:18. HTS Teologiese Studies, 65(1), Art. \#306, DOI: 10.4102/hts.v65i1.306. 1-7.

Verenigende Gereformeerde Kerk in Suider-Afrika. 2005. Agenda of the Fifth General Synod of the Uniting Reformed Church in Southern Africa, 29 September - 5 October 2005, Hammanskraal.

Verenigende Gereformeerde Kerk in Suider-Afrika. 2012. Minutes of the Sixth General Synod of the Uniting Reformed Church in Southern Africa, 1 - 7 October 2012, Okahandja, Namibia.

Vorster, J. 2007. Christian Attitude in the South African Liberal Democracy. Potchefstroom: PTP.

Vorster, J. 2016. The general revelation of God and creational gifts as a source for bioethics. Luce Verbi, 50(1), a2083. http://dx.doi. org/10.4102/ids.v50i1.2083. 1-7. 